\title{
http://jaet.journals.ekb.eg \\ Environmental Impacts Assessment of Rice Straw Brick as a Substitutional Sustainable Building Material in Assiut University Hospital Clinic
}

\author{
Ahmed AbdelMonteleb Mohammed Ali \\ Assistant Professor, Department of Architecture, College of Architecture and Planning, Qassim University, \\ Qassim, 52571, Saudi Arabia \\ Email:ahm.ali@qu.edu.sa,TEL: +966532490093 \\ Assistant Professor, Department of Architectural Engineering, Faculty of Engineering, Assiut University, \\ Assiut, 71515, Egypt \\ Email: ahmed.abdelmonteleb@aun.edu.eg, TEL: +201005490811
}

\begin{abstract}
The rice straw burning in all the Egyptian governorates is seasonally occurring, an environmental disaster called the "Black Cloud". This study's main goal is to conduct the Life Cycle Assessment (LCA) and Building Information Modeling (BIM) methods. Thus, the LCA of four brick types: (1) fired clay, (2) cement, (3) sand, and (4) rice straw has been compared. The BIM has been used to gather the building construction components to build the four LCA scenarios using the PRe SimaPro. The results have been presented by the single score and weighting method using the IMPACT 2002+ method with midpoint and endpoint $(\mathrm{Pt})$ results. (1) Regarding the midpoint results, the fired clay brick has recorded the worst environmental impact with $30.10 \mathrm{Pt}$. In contrast, the rice straw brick has verified the lowest effects with 1.31 Pt. (2). Regarding the endpoint results, the highest value of human health has been assigned to the fired clay brick type with $11.4 \mathrm{Pt}$ and the rice straw brick with $0.633 \mathrm{Pt}$. The highest resource depletion impacts have been pointed out the fired clay and cement brick with 7.29 Pt and 6.53 Pt, respectively. A novel framework for integrating LCA and BIM has been conducted on a proposed building during the early phases. The article has also introduced an approach to eliminating the Egyptian life cycle inventory database shortage as the LCA applications in Egypt are scarce. Moreover, it can help the concerned legislative bodies and the decision-makers.
\end{abstract}

\section{KEYWORDS}

Environmental Impact Assessment (EIA), Life Cycle Assessment (LCA), Building information modeling (BIM), Rice Straw Brick, Assiut City

\section{Highlights}

- Incineration of the rice straw in the Egyptian governorates is seasonally occurring, and an environmental disaster called the "Black Cloud".

- LCA and BIM methods have been conducted for four brick types on a proposed building during the early phases.

- The rice straw brick industry does not use natural resources and fuel in large quantities than the fired clay brick.

- Due to the fired clay production incineration process, the highest value of the human health impact has been assigned to the fired clay brick.

- The highest resource depletion impacts have been pointed to the cement brick industry as it is using lime as a primary material to produce the brick.

Received:14 February, 2021, Accepted:3 April, 2021

\section{Nomenclature \\ Chemical composition \\ $\mathrm{CO}_{2} \quad$ Carbon dioxide $\quad \mathrm{SO}_{2} \quad$ Sulfur dioxide \\ $\mathrm{CH}_{4}$ Methane $\mathrm{NO}_{\mathrm{x}} \quad$ Nitrogen \\ oxide \\ $\mathrm{N}_{2} \mathrm{O} \quad$ Nitrous oxide $\quad \mathrm{NH}_{3} \quad$ Ammonia \\ $P M \quad$ Particulate per $\quad \mathrm{C}_{2} \mathrm{H}_{4} \quad$ Ethylene matter}

\section{Measurement units}

$\begin{array}{llll}P t & \text { Eco-points } & \mathrm{kg} & \text { Kilogram } \\ \mathrm{m}^{3} & \text { Cubic meter } & \mathrm{kg} / \mathrm{m}^{3} & \text { Density } \\ \mathrm{m}^{2} & \text { Square meter } & \mathrm{kg} \mathrm{CO} 2 & \text { Kilogram } \\ & & \mathrm{eq} & \begin{array}{l}\text { carbon dioxide } \\ \text { equivalent }\end{array}\end{array}$

\begin{tabular}{ll}
\multicolumn{2}{l}{ Abbreviations } \\
LCA & Life Cycle Assessment \\
BIM & Building Information Modeling \\
ISO & International Standards Organization \\
PVC & Polyvinyl chloride \\
AUHC & Assiut University Hospital Clinic
\end{tabular}




$\begin{array}{ll}\text { CED } & \text { cumulative energy demand } \\ \text { DFP } & \text { Depletion-fossil fuel potential } \\ \text { LCI } & \text { Life cycle Inventory } \\ \text { LCIA } & \text { Life cycle Impact Assessment } \\ \text { HH } & \text { Human Health } \\ \text { GHG } & \text { Greenhouse Gas } \\ \text { GWP } & \text { Global Warming Potential } \\ \text { AU } & \text { Assiut University campus }\end{array}$

\section{Introduction}

In 2010, the Industrial Pollution Control Policies in Egypt [1] had reported that 345 major industrial projects had been investigated; around 311 were brick factories, which describes the massive demand of the brick industry in Egypt. The brick industry has two sides, the first is the fuel used, and the second is the raw materials consumed. As for the fuel used, traditional manufacturing was the agriculture residue and dung cakes in brick stoves, as reported in Eldorghamy [2]. As a biomass combustion technology, this was the oldest bioenergy technology in Egypt. After that, liquefied petroleum gas (LPG) and kerosene have replaced this technology. However, biomass combustion technology is still used in rural communities and ranked $17 \%$ of the total fuel used. There was a sun-dried brick, has been used in the old one-story buildings as it cannot afford structure loads. The primary pollutant of the brick industry is the carbon dioxide $\mathrm{CO}_{2}$ besides the Lead, Sulfur dioxide, Nitrogen dioxide, and suspended particulate matter. In the brick industry, the leading cause of these emissions is the smelters, and the brick kilns, as EGYPT'S FIRST BIENNIAL reported [3]. The greenhouse gas (GHG) emissions, as is reported by Dabaieh [4], are greenhouse gas (GHG) emissions are the worst environmental impacts of brick manufacturing during industrial and transportation procedures. The life cycle assessment (LCA) has been introduced in many studies as environmental impact assessment tools to assess these emissions. The literature review will handle this point. The LCA is a process technique to assess the environmental burdens by determining the quantities and energy, material used, and emitted emissions from the products, process, and activities analysis.

On the other hand, the brick industry's raw materials, as traditional brick, have used the Nile mud material, which is a natural material. Still, now this is the primary raw material in Egypt, which leads to the scraping of agricultural lands then the depletion of the resources (RD), which will be one of the leading environmental problems. Many raw materials are introduced, such as sand and cement, as an alternative raw material of the mud. Each type of them has the leading mechanical and bearing characteristics from a civil point of view. Also, the mechanism of manufacturing will be different. To produce clay brick from using the mud, the fired technology, burning in open kilns, will be used, which is considered the environmental worst case. Cement and sand brick are usually using mechanical and electrical mechanisms; however, sand is one of the natural materials, and cement has the own environmental emission in its industry.

Turning into the rice straw as an alternative material to produce brick, Egypt has an evident seasonal phenomenon: the black cloud. It is a thick layer of emission because of the rice straw's burning in all Egyptian governorates. The Ministry of Environment has introduced many initiatives, the Egyptian Environmental Affairs Agency, to motivate the farmers to eliminate the burning process, leading to imposing hefty fines. In 2017, there was an initiative to turn the rice straw waste to be a by-product. In Cairo, as one of the Egyptian governorates, there were 840,000 fedans as cultivated with rice amounts [3]. In 2019, 1,900 tons of rice straws were gathered from cultivated areas in 156 sites [1]. Egypt produces annually 30 million tons of agricultural waste and emits 80,000 tons of $\mathrm{CO}_{2}$ emission. The rice straw price in Egypt has been estimated as much as $\$ 50.25$ per ton [5]. Ahmed Farag et al. [6] reported in Tables 3 and 4 the rice cultivation allocation in Egypt and the carbon dioxide emissions from the rice straw burning. The results showed the most emissions had been emitted from the lower Egypt zone. Nowadays, it becomes clear that there is an urgent necessity to take advantage of rice straw waste as an alternative material for producing bricks in Egypt.

Introducing the most sustainable alternative materials is the principal scientific point nowadays. Fuel and raw materials are the most significant challenges to create new sustainable materials. This article will deal with the rice straw materials as a substitutional material to the brick industry's limestone. It helps reduce the environmental impacts from its incineration process as a lousy phenomenon in Egypt. In the next section, the research will introduce contemporary studies in this field.

\section{Literature review}

All industries, which cause environmental emissions and depletion of RD, have been investigated by many searches. This article will review recent studies regarding the brick industry in general and mainly introducing the substitutional sustainable building material.

Ramos Huarachi [7] has reported a review study on the LCA of bricks to characterize and guide future researches. This study investigated the traditional brick type, and the types that have used the waste material to manufacture the bricks - one of the findings of this 
research is that it is tough to replace the firing process. The LCA methodology has been used in this study to calculate climate change as an environmental impact category. Drying and incinerating procedures in the production process were the worst environmental impacts. Ultimate, the article has recommended for future studies to introduce new raw materials and biomass as fuel in the incinerating procedures.

Marwa Dabaieh [4] has unveiled a comparative study between sun-dried and fired clay bricks using the LCA approach and embodied energy investigation. The sundried brick is a traditional type that has been used in Architecture Hassan Fathy's concept. The study's result experienced a decline in the $\mathrm{CO}_{2}$ emission and the embodied energy quantities using the sun-dried brick rather than the fired one. Finally, the study has presented specific alternative scenarios, such as using the PV systems as a renewable energy supplier and using the alternative fuels as natural gases for the brick firing process, and using the building wastes to replace the clay, sand, and shale materials.

In August 2019, an investigation was conducted by Dalia Yacout [8]. During 2006 -2019, there were 39 LCA studies had been published in Egypt. It indicates the necessity to encourage LCA applications to assess environmental impacts as a sustainable methodology in Egypt. Around 44\% (17 studies) of these studies have been applied to construction and building materials. Seven studies were on cement and brick over the past 13 years, which is very clear that there is an apparent deficiency in the LCA applications. Only one article, Gihan Garas [9], studied some agricultural waste materials for building materials manufacturing in 2016. Such as the burning of straw rice in Egypt; in India, field burning is seasonally occurring, causing harmful emissions. Athira et al. [10] have revealed the practical usage of the rice straw as a biomass fuel to reduce the non-renewable fossil fuels and as a by-product to use in the construction industry. One of the different rice straw usage as a co-product, Abdel Daiem et al. [11], has studied the potential energy from mixing the rice straw and sewage sludge. Furthermore, Jittima Prasara [12] has introduced scenarios to maximize the benefits of rice straw's environmental use in Thailand.

A comparative analysis of three biomass fuels has been investigated by Rutjaya et al. [13]. The three types were cane leaves, rice straw, and rice husk. The results have released that the cane leaves and rice straw has recorded the lowest environmental impacts. The most extensive burden environment was the burning process. Finally, the research has recommended using the rice straw as a fuel type and co-product to produce the brick. Other articles have investigated the structural bearing of using straw rice as a brick type, such as Alessandro et al. and Eman Ali et al. [14], [15].

\section{Materials and methods}

3.1. Environmental Impact Assessment approach The environmental assessment tools for the construction building material are very massive; in this section, the author will clarify these tools' analysis and grouping. The earliest actual trial was in 1999, the Building Research Establishment Environmental Assessment Method (BREEAM); this was the first environmental assessment tool specifically for the buildings [16], [17]. In 2006, the International Standards Organization ISO became the most acknowledged standards with many series to develop buildings' environmental assessment. The ISO published these standards, shown in Figure 1.

- ISO 14040: Environmental management, LCA, Principles, and framework [18].

- ISO 14041: Environmental management, LCA, Goal definition and inventory analysis [19]

- ISO 14042: Environmental management, LCA, Life-cycle impact assessment [20].

- ISO 14043: Environmental management, LCA, Life-cycle interpretation [21].

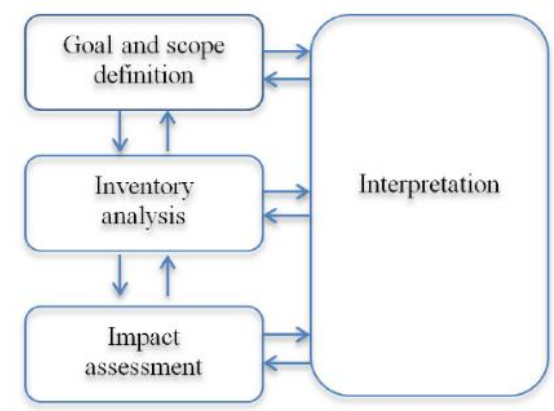

Figure 1 LCA framework defined by ISO [22] As presented in the introduction and literature review, the author will use the LCA methodology to assess different brick types' environmental impacts using the PRe SimaPro version 9.1 with a faculty license. Indeed, this paper is one of the series of LCA studies on the Assiut University Hospital Clinic as a case study, two articles have been already published [23], [24].

\subsection{Building Information Modeling}

One approach that can be used to calculate energy consumption and environmental emissions is the LCA tool. LCA permits the investigation of the two calculations that are linked with the building [25]. Building Information Modeling (BIM) comes to be the best choice to gather the building construction components and facilitate this task. The LCA-BIM incorporation in the construction material can significantly evaluate and deliver the sustainability 
Vol. 41, No.2. July 2022

features. This integration has been introduced in many previous studies; all of them were summarized in Senem Seyis and Shu Su et al. [26], [27]. The author will apply the integrated approach in this study; this integration will combine LCA and BIM strengths. The LCA will provide an analysis of the environmental impact of specific scenarios. Besides that, the BIM will offer the construction material data to be the inputs of the LCA. The most popular BIM software is Autodesk Revit. This research will use the 2020 student licensed version, as presented inFigure 2.

\subsection{Case study analysis}

Assiut University Hospital Clinic (AUHC) is a proposed project held inside the Assiut University campus (AU). Figure 3 shows the google earth of the campus. Also, Figure 4 presents the location of the proposed new clinic.

Taking the advantages of the BIM approach, the geographic location has been set in the Revit. The longitude and latitude are defined with coordinators 27.1838397979736 and 31.1667556762695, respectively. Furthermore, Figure 5 documents a sample of BIM model drawings.

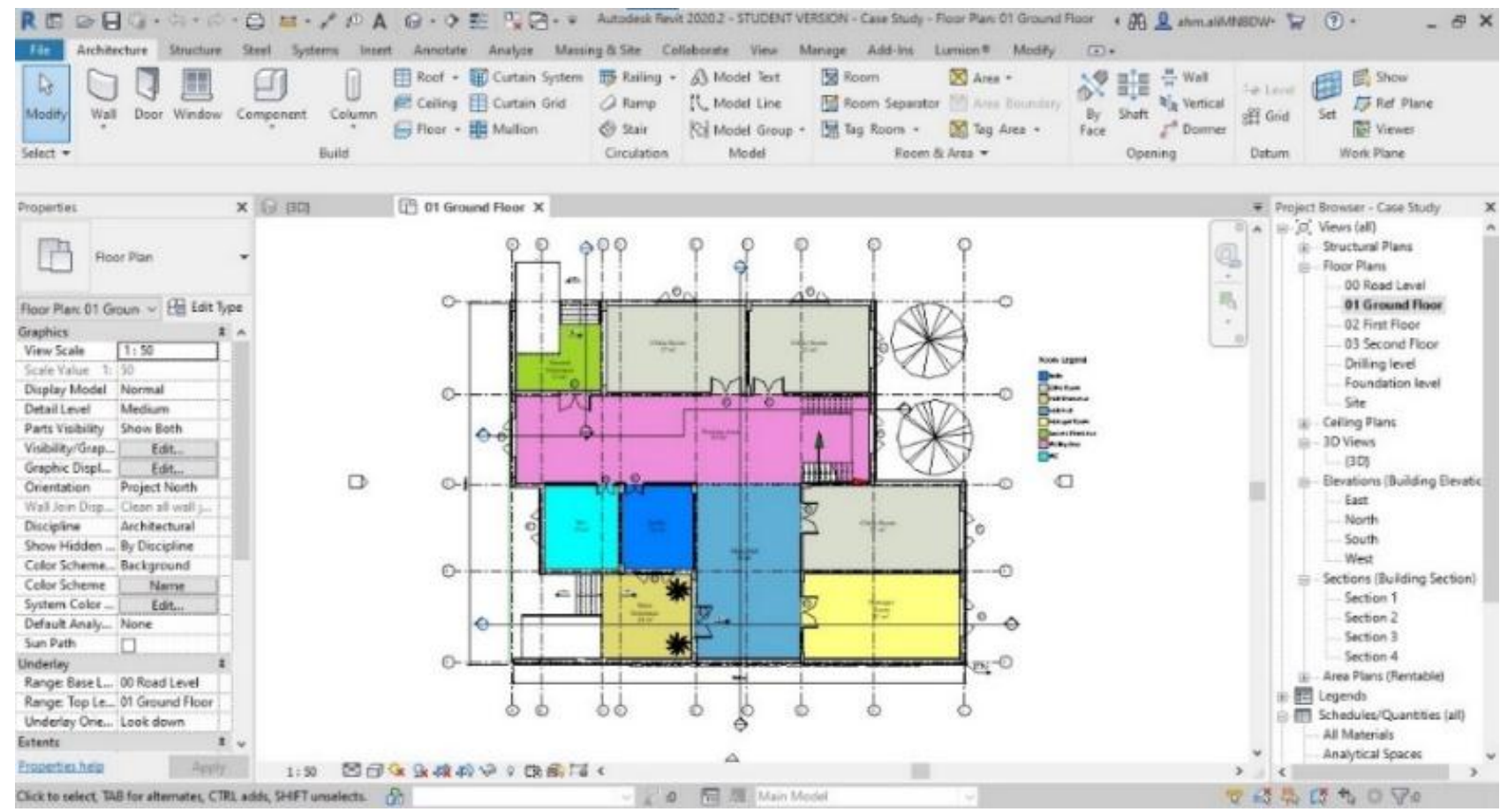

Figure 2 Autodesk Revit user interface version 2020 licensed version 
Vol. 41, No.2. July 2022

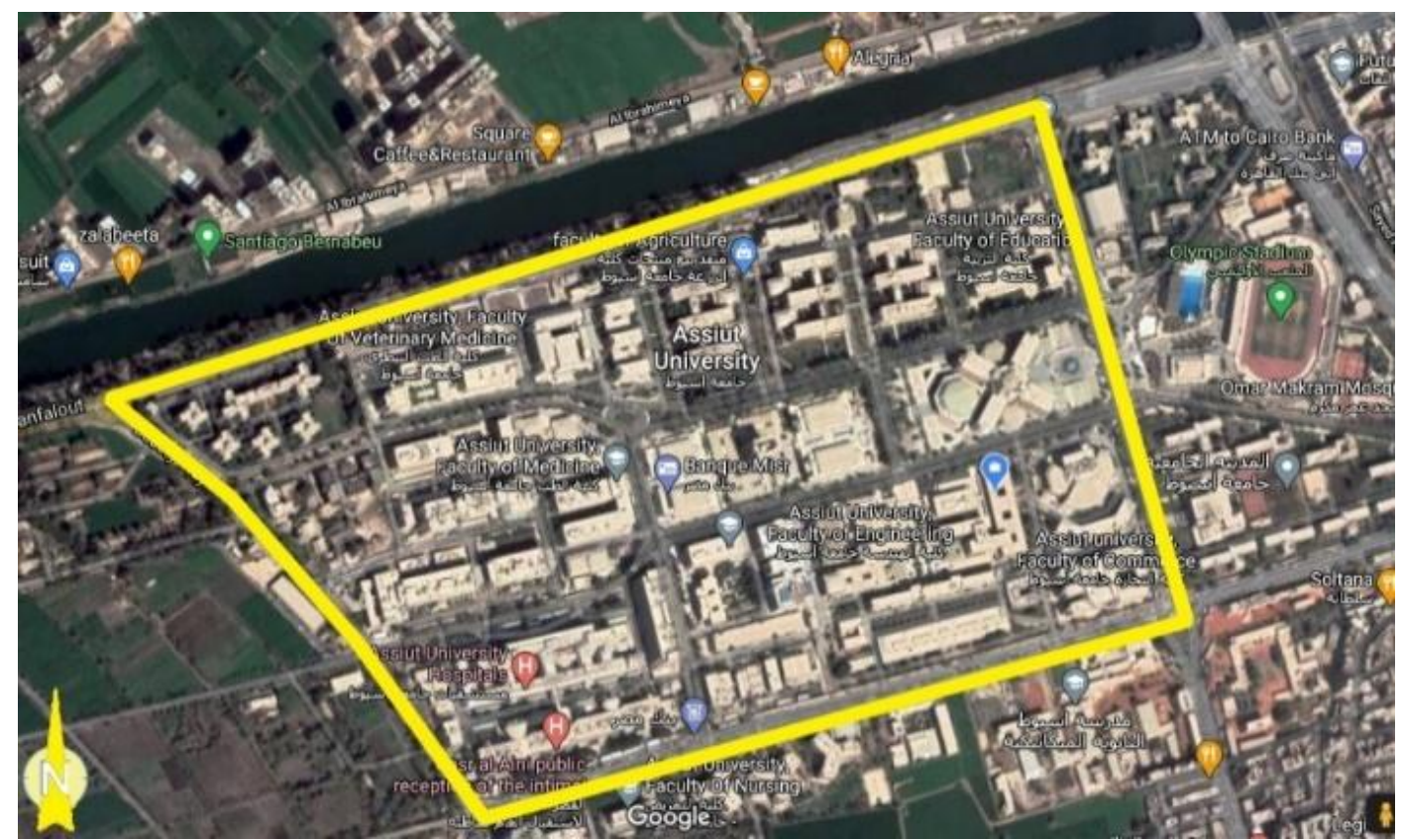

Figure 3 Location of the campus of Assiut University in Assiut city, Egypt

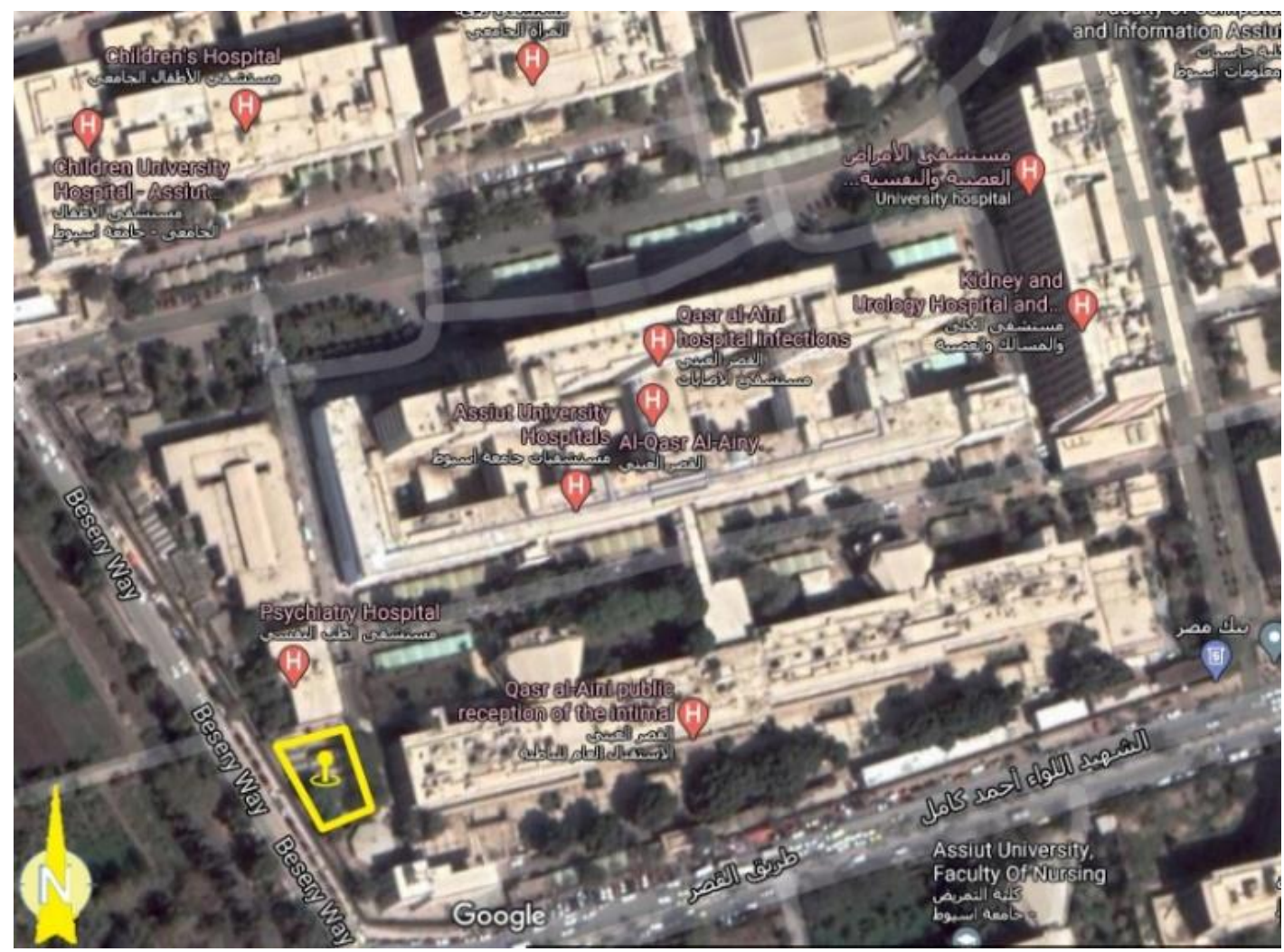

Figure 4 Location of the proposed new clinic in AUH 
Vol. 41, No.2. July 2022

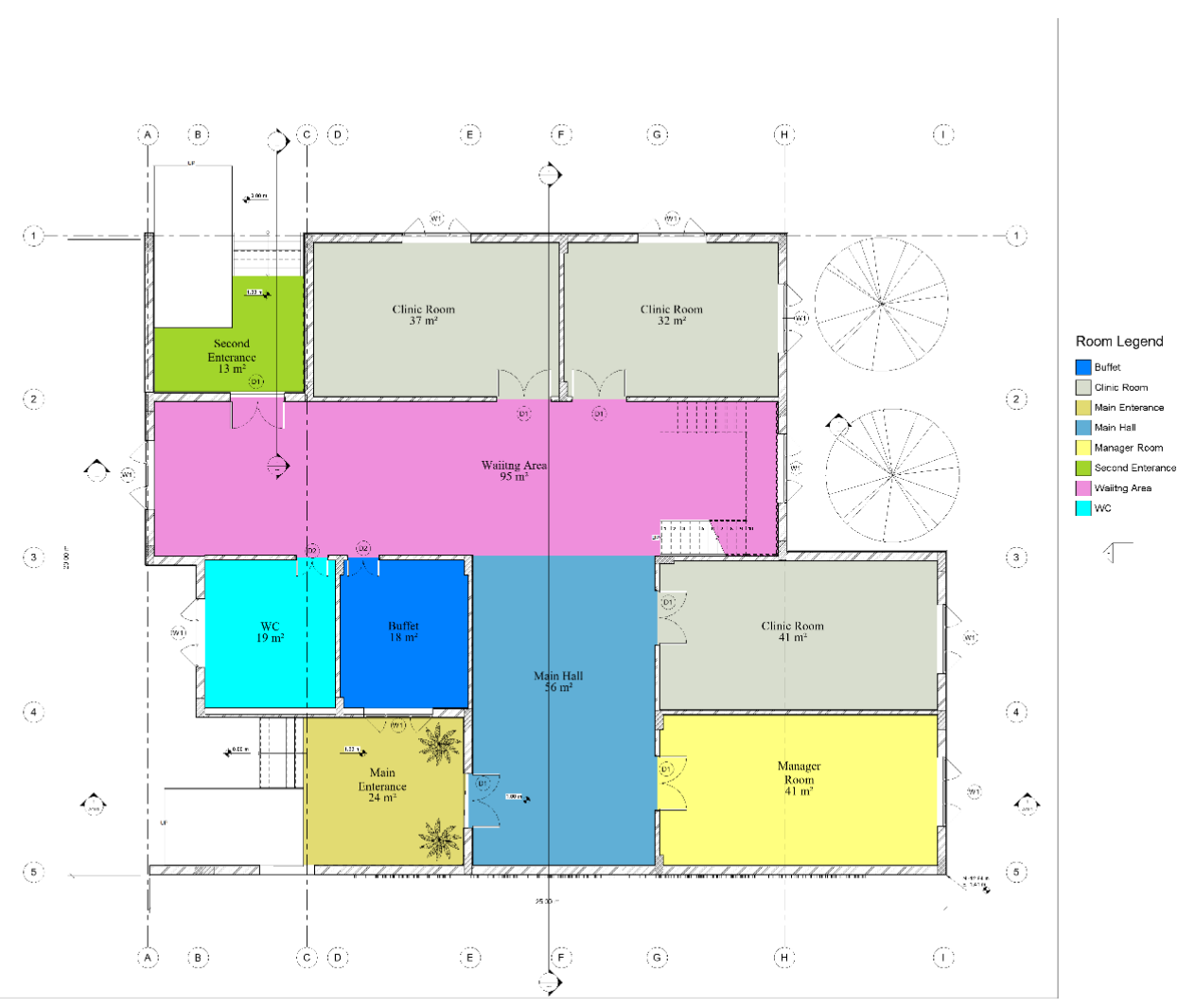

a) The ground floor

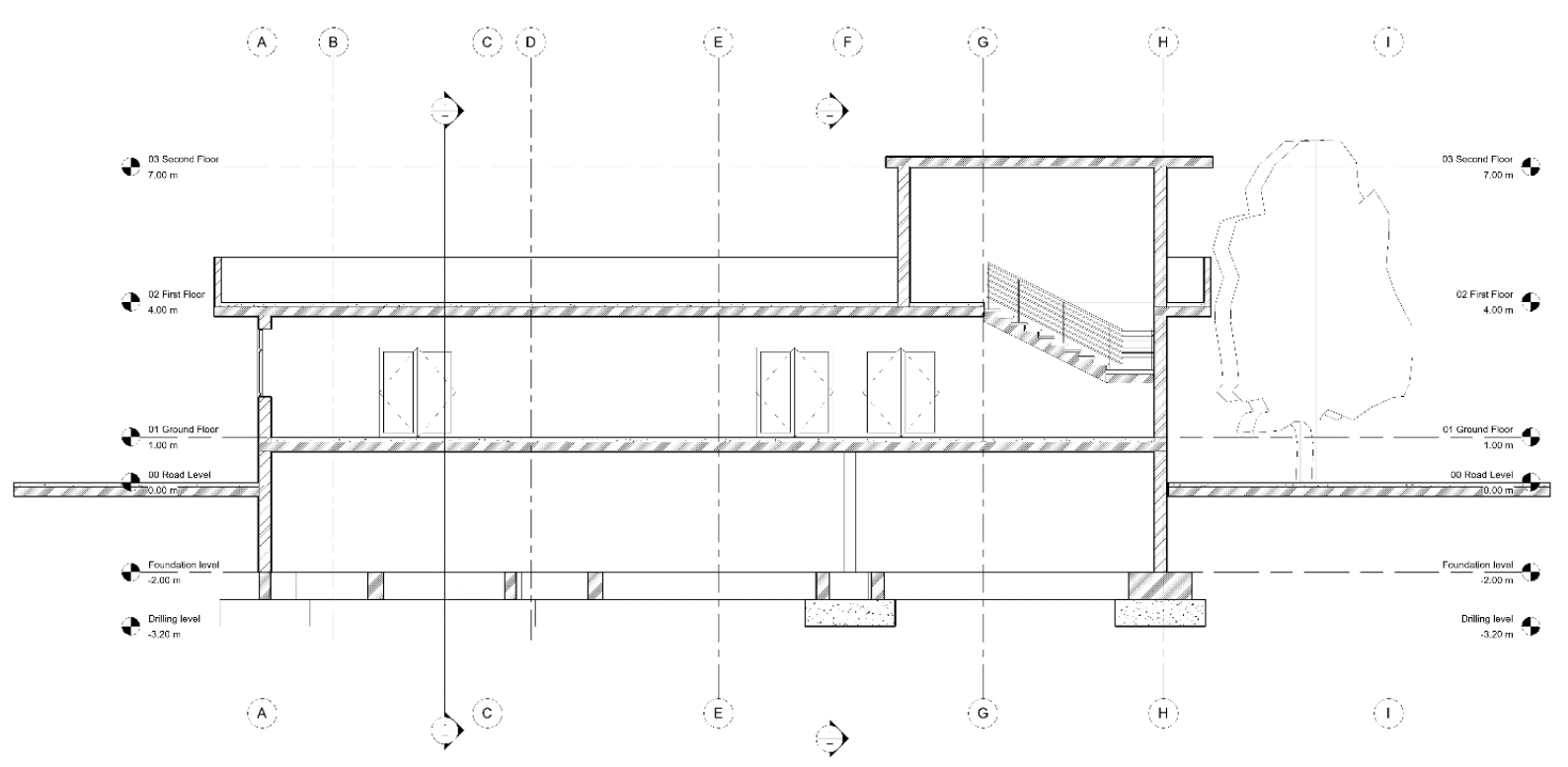

b) The building section 


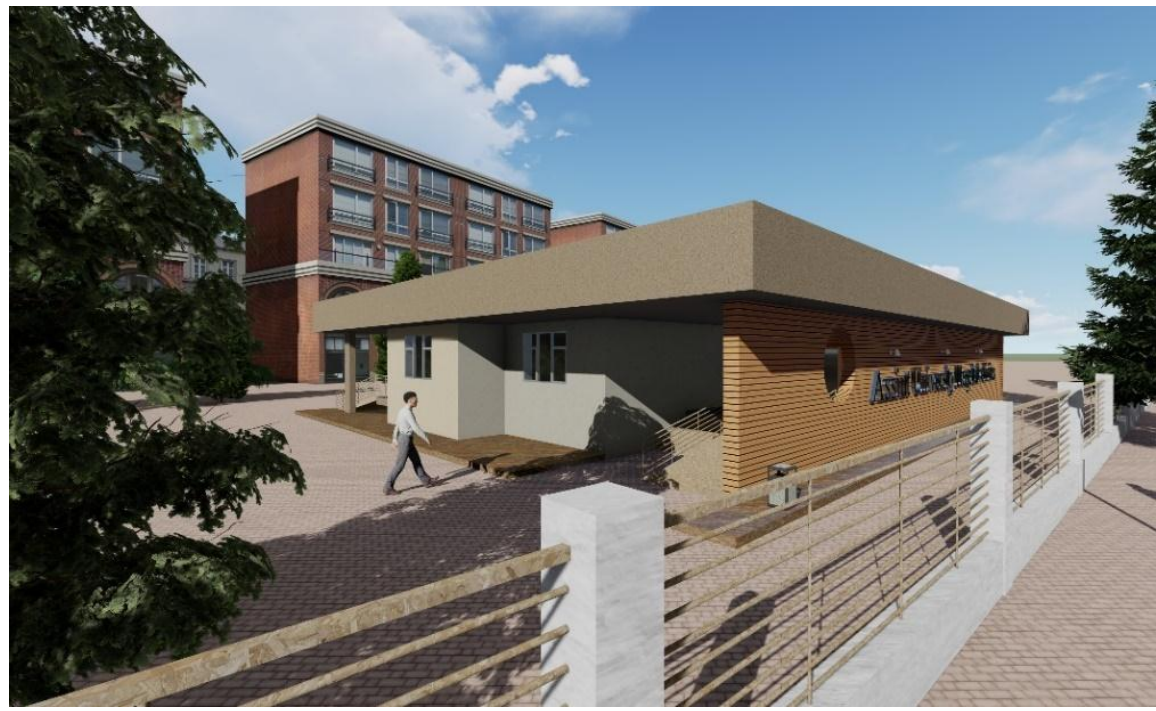

c) A proposed perspective

Figure 5 BIM model documents

\subsection{Comparative LCA of brick types}

Due to the massive usage of brick as one of the main components in Egyptian buildings, this study will introduce the usual brick types used in the building industry: the fired-clay, cement, and sand brick. The flow chart of the construction of these brick types is

shown in Figure

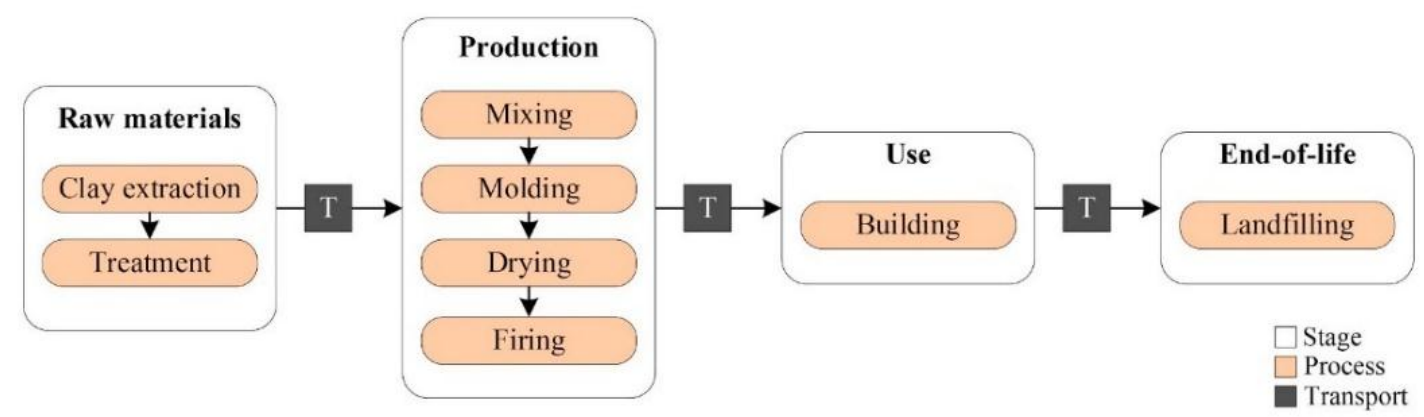

Figure 6 Life cycle assessment of the three brick types from cradle-to-grave [7].

On the other hand, it is substantial to evaluate the manufacturing process and the environmental impacts of the alternative brick type through its life cycle to explain which type of bricks are less in environmental emissions. Figure 7 depicts the flow chart of the rice straw brick manufacturing. The chart includes acquiring the raw materials, energy consumed, water consumed, and emissions from each brick industry stage. All these data will be the SimaPro software inputs to assess the environmental impact categories, as will be shown later.

\section{Life Cycle Assessment Methodology \\ 4.1. Goal and scope}

The goal of this study is to compare the four brick types: (1) fired clay brick, (2) cement brick, (3) sand brick, and (4) rice straw brick. Using the BIM model, the material quantities have been calculated and inputted in the PRe SimaPro to investigate the environmental impacts. The functional unit (FU) will be one kilogram $(1 \mathrm{~kg})$ for each type. The system boundary of this study has been defined to be from the cradle to the site only. There are raw materials, electricity, fuel usage as inputs, and emissions as outputs; these data have been gathered from the literature reviews and drawn in SimaPro.

\subsection{Life cycle Inventory database}

Table 1 lists all building materials; all these numbers have been calculated according to the FU. These materials are extracted from BIM output to be inputted in SimaPro software. As the deficiencies of LCA applications and inventory dataset in Egypt, this study has relied on the Ecoinvent V3 dataset, a European 
data, and already embodied in the SimaPro software and considering a minimal error in the results.

Table 1 Material quantities from the BIM model

\begin{tabular}{lll}
\hline Name & Area $\left(\mathrm{m}^{2}\right)$ & Volume $\left(\mathrm{m}^{3}\right)$ \\
\hline Brick & 861 & 164.16 \\
Concrete & 4382 & 0.88 \\
Steel & & 17.00 \\
Mortar & 3089 & 29.70 \\
Tiles & 1556 & 62.29 \\
Glass & 132 & 0.41 \\
$\begin{array}{l}\text { Plaster } \\
\text { Wood/Aluminum }\end{array}$ & 3358 & 32.31 \\
window frames & & \\
opening & 88 & 1.20 \\
\hline
\end{tabular}

\subsection{Life cycle impact assessment (LCIA)}

The life cycle impact assessment is the third phase of the ISO standards, as shown in Figure 1. The main aim of this stage is to distinguish among the environmental impacts of the materials. The emission from the life cycle inventory (LCI) is converted to LCIA using some equations in the SimaPro, such as characterization, normalization, weighting, and a single score. According to the literature review, many life cycle impact categories have been introduced; however, these articles [28]-[31] have used the IMPACT 2002+ to examine their case studies. In this study, the author will rely on the IMPACT 2002+ with two approaches: the midpoint and endpoint methods. Global warming, aquatic ecotoxicity, respiratory and non-renewable energy have been covered in the midpoint method, with equivalent (eq) results. The second method involves human health (HH) damage, ecosystem quality (EQ), and resource depletion (RD). All of them are

shown

[32].

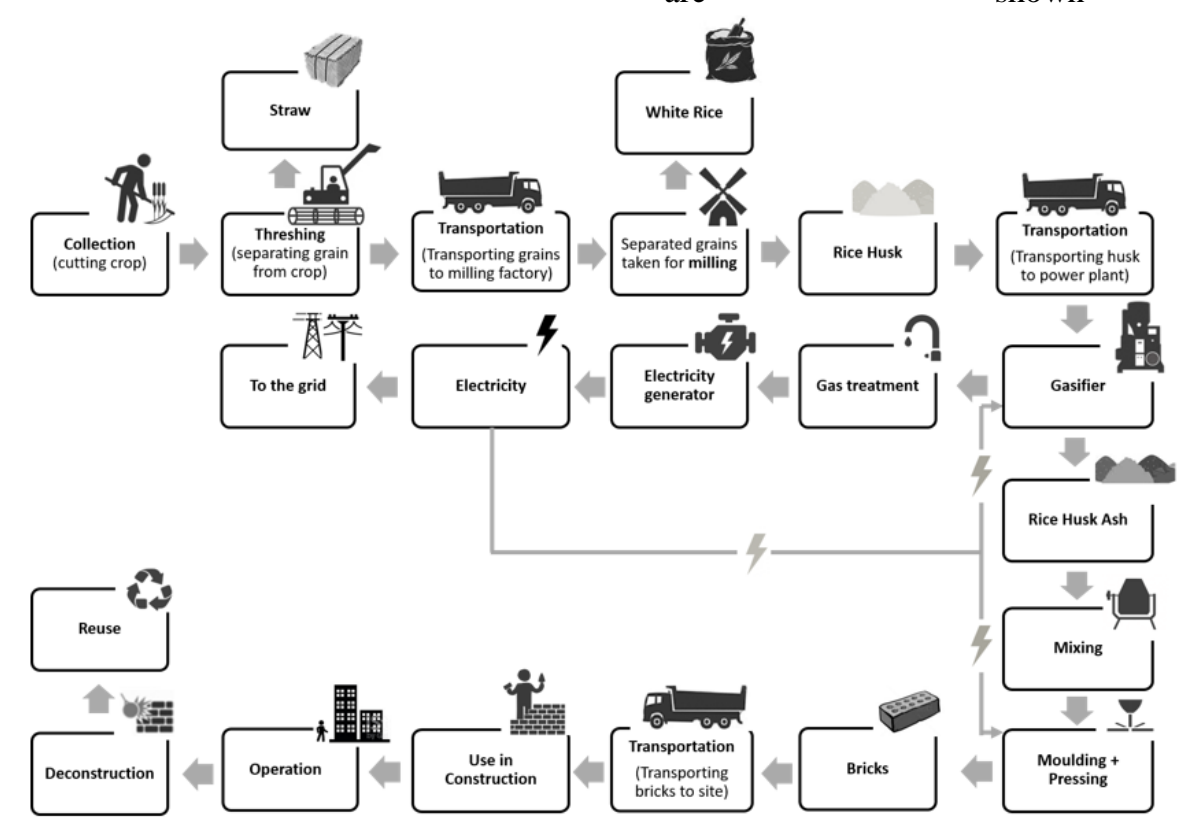

Figure 7 Life cycle assessment of the rice straw brick from cradle-to-grave

\section{Results and discussions}

The results of the comparative analysis will be unveiled in this section. The author will divide the findings into three sectors: Single Score and weighting method using the IMPACT 2002+ method discussed in the LCIA part. The single score and weighting results have been presented by point $(P t)$ as a unit.

\subsection{Single Score method per impact category}

Based on each material's network flow, the single score method results as an LCIA finding came out in Figure 8. The fired clay brick has recorded the highest environmental impact, which is the worst case with $30.10 \mathrm{Pt}$. In contrast, the rice straw brick has verified the lowest impacts with $1.31 \mathrm{Pt}$, also has documented some small and ignored impacts with negative. This result's interpretation is that the rice straw does not use natural resources and fuel in large quantities than the fired clay brick and others compatible with [13] results. Turning to the cement and sand brick, have been recorded the middle ranks with $14.20 \mathrm{Pt}$ and $10.80 \mathrm{Pt}$ respectively in consistent with [33], [34]. In that meanwhile, the author should document that there is a cut-off of the cement industry in the cement brick calculation. The sand brick is mainly using the wet mixture and electrical machine to press the molds. 
Vol. 41, No.2. July 2022

Figure 9 highlights the endpoint results. This method will present the endpoint environmental impacts, specifically the $\mathrm{HH}$ and RD. The HH's highest value has been assigned to the fired clay brick type with 11.4 $P t$, and the rice straw brick with $0.633 P t$, this due to the incineration process of the fired clay production as reported in Garas et al. [35]. The highest resource depletion impacts have been pointed out the fired clay and cement brick with 7.29 Pt and 6.53 Pt respectively in agreement with [34], [36]. To interpret this result, that the two brick types are using lime as a primary raw material to produce their brick.

\subsection{Weighting method per impact category}

In this part, the author will present weighting results per impact category, as shown in Figure 10. Firstly, in the fired clay brick, the respiratory inorganics impact has recorded the highest impacts with $10.30 \mathrm{Pt}$. The emissions of particulate per matter (PM) are very high in the fired clay brick due to the fuel used in the firing process, also [7], [13] support this result. Secondly, the non-renewable energy impacts are very high in the cement brick with $6.53 \mathrm{Pt}$. Using the impact of non- renewable energy sources is the greenhouse gases emission. This is because of the carbon dioxide, methane releasing into the atmosphere. The main sources of non-renewable are burning the fossil fuels as it is reported in [10], [11], [36], [37]. Thirdly, the respiratory inorganics impact has recorded highest in the sand and rice straw brick types but after the fired clay brick rank.

In conclusion, offering sustainable building materials is very important to maximize environmental and energy optimization. Egypt is suffering from; (1) Human health deterioration and natural resource depletion since the brick industries are still using limestone as a primary raw material. (2) Using fossil fuel in the firing process. (3) Incineration of the rice straw in the Egyptian governorates is seasonally occurring. To summarize, the fired clay brick has recorded the highest environmental impacts, and the rice straw brick has noted the lowest impacts. The industry improvements, sustainable alternative materials, and substitutional fuels should be introduced from the stakeholders and decision-makers.

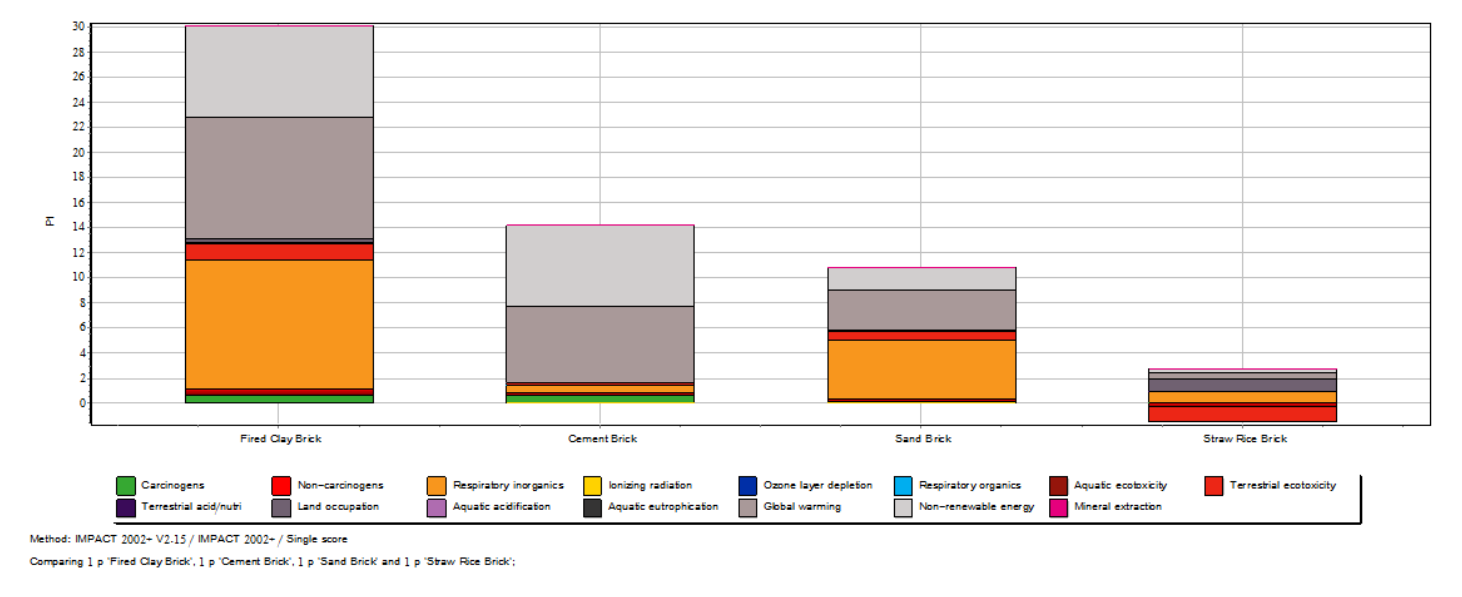

Figure 8 Single score results per impact category (Midpoint method) 


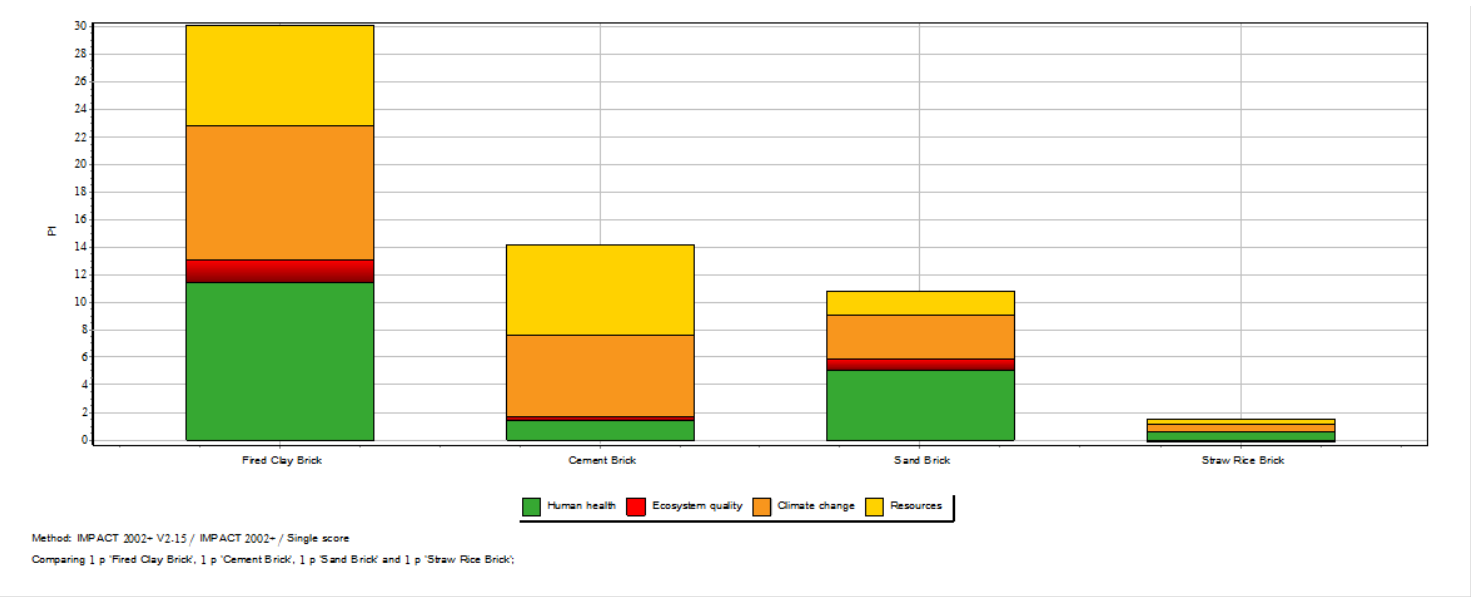

Figure 9 Single score results per brick type (Endpoint method)

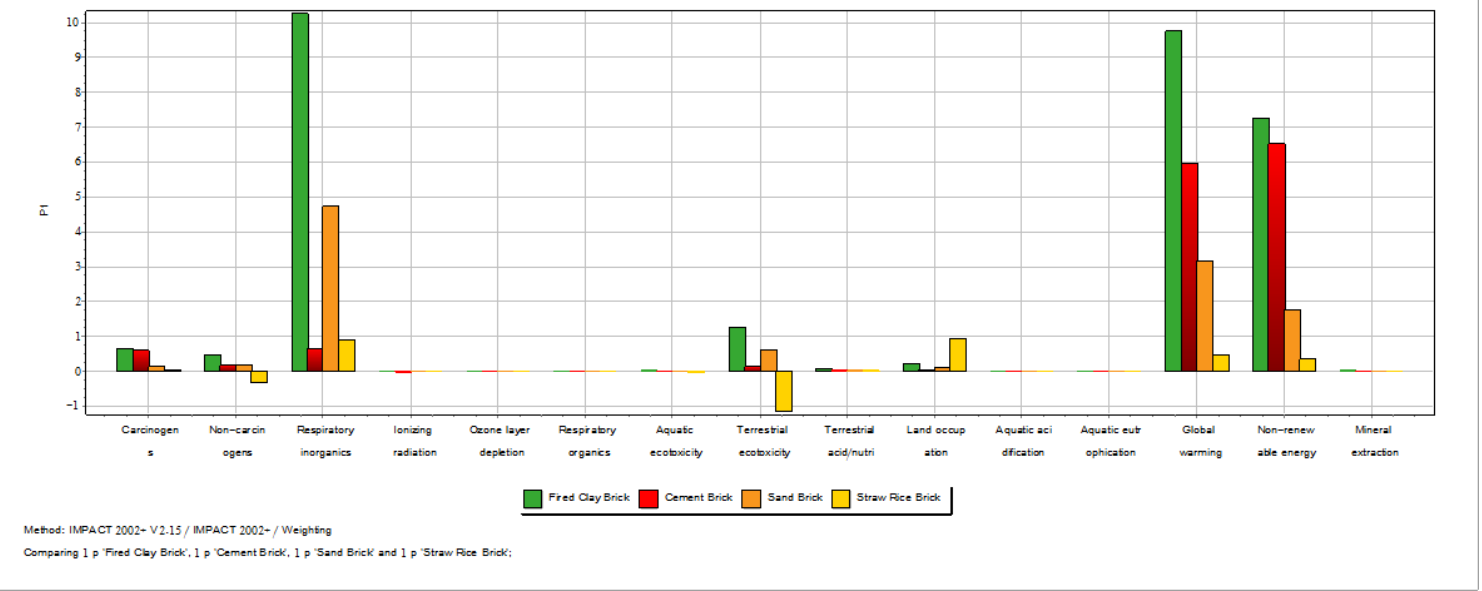

Figure 10 Weighting results per impact category (Midpoint method)

\section{Limitation and Recommendation}

The main obstacles and challenges indicate that essential points should be considered. The designers should use the BIM application for all projects. The lack of an Egyptian LCI database is the main barrier to apply the LCA for all proposed projects in Egypt. The author recommends using the European dataset to apply the LCA in Egyptian case studies by selecting the global industry and market data from the Ecoinvent database. This study has presented a method of selecting the building materials' database from the Ecoinvent to apply the LCA application in Egypt. Therefore, the life cycle inventory dataset and analysis outcomes provided in this research are anticipated to help designers better understand building material selection and system improvement from the whole life cycle perspective.

\section{Declaration of competing interest}

The author declares that he has no known competing financial interests or personal relationships that could have influenced the work reported in this research.

\section{References}

[1] EEAA, "Industrial Pollution Control Policies in Egypt," pp. 1-85, 2010, [Online]. Available: http://www.eeaa.gov.eg/portals/0/eeaaReports/ EPAP/Proper/Industerial Policy/Industerial Pollution policy in Egypt English.pdf.

[2] A. El-dorghamy, "Energy and Environmental Management in Egypt Bioenergy CDM projects," Royal of Institute of Technology, Stockholm, 2007.

[3] E. E. A. A. Ministry of Environment, Egypt's first Biennial Update Report to the United Nations Framework Convenstion on Climate Change. 2018.

[4] M. Dabaieh, J. Heinonen, D. El-Mahdy, and D. M. Hassan, "A comparative study of life cycle carbon emissions and embodied energy between sun-dried bricks and fired clay bricks," J. Clean. Prod., vol. 275, p. 122998, 2020, doi: 10.1016/j.jclepro.2020.122998.

[5] M. E. and N. A. R. Sustainable Development Department, "The Arab Republic of Egypt For 
better or for worse: Air pollution in Greater Cairo," 2013.

[6] M. A. M. H. Ahmed Awny Farag, Hanafi A Radwan, Mohamed A. A. Abdrabbo, "Carbon Footprint for Paddy Rice Production in Egypt," Nat. Sci., vol. 11, no. 12, pp. 36-45, 2013, [Online]. Available: http://www.sciencepub.net/nature.

[7] D. A. Ramos Huarachi, G. Gonçalves, A. C. de Francisco, M. H. G. Canteri, and C. M. Piekarski, "Life cycle assessment of traditional and alternative bricks: A review," Environ. Impact Assess. Rev., vol. 80, no. September 2019, p. 106335, 2020, doi: 10.1016/j.eiar.2019.106335.

[8] D. M. M. Yacout, "Assessing Status of Life Cycle Assessment Studies in Egypt," vol. 2, no. August, pp. 177-189, 2019, doi: 10.14456/cast.2019.15.

[9] G. Garas, E. Bakhoum, and M. Allam, "Optimal use of selected waste materials in buildings," Ecol. Environ. Conserv., vol. 22, no. 3, pp. 1129-1136, 2016.

[10] G. Athira, A. Bahurudeen, and S. Appari, "Sustainable alternatives to carbon intensive paddy field burning in India: A framework for cleaner production in agriculture, energy, and construction industries," J. Clean. Prod., vol. 236, p. 117598, 2019, doi: 10.1016/j.jclepro.2019.07.073.

[11] M. M. Abdel Daiem, N. Said, and A. M. Negm, "Potential energy from residual biomass of rice straw and sewage sludge in Egypt," Procedia Manuf., vol. 22, pp. 818-825, 2018, doi: 10.1016/j.promfg.2018.03.116.

[12] M. B. Ahsan and Z. Hossain, "Comparative Life Cycle Assessment of Rice Husk Utilization in Thailand," 2009.

[13] R. Prateep Na Talang, M. Pizzol, and S. Sirivithayapakorn, "Comparative life cycle assessment of fired brick production in Thailand," Int. J. Life Cycle Assess., vol. 22, no. 11, pp. 1875-1891, 2017, doi: 10.1007/s11367-016-1197-3.

[14] F. D'Alessandro, F. Bianchi, G. Baldinelli, A. Rotili, and S. Schiavoni, "Straw bale constructions: Laboratory, in field and numerical assessment of energy and environmental performance," J. Build. Eng., vol. 11, no. January, pp. 56-68, 2017, doi: 10.1016/j.jobe.2017.03.012.

[15] E. N. Ali, S. R. Alfarra, M. M. Yusoff, and M. L. Rahman, "Environmentally Friendly Biosorbent from Moringa Oleifera Leaves for
Water Treatment," Int. J. Environ. Sci. Dev., vol. 6, no. 3, pp. 165-169, 2015, doi: 10.7763/ijesd.2015.v6.582.

[16] A. Haapio and P. Viitaniemi, "A critical review of building environmental assessment tools," Environ. Impact Assess. Rev., vol. 28, no. 7, pp. 469-482, 2008, doi: 10.1016/j.eiar.2008.01.002.

[17] E. Meex, A. Hollberg, E. Knapen, L. Hildebrand, and G. Verbeeck, "Requirements for applying LCA-based environmental impact assessment tools in the early stages of building design," Build. Environ., vol. 133, pp. 228236, Apr. 2018, doi: 10.1016/j.buildenv.2018.02.016.

[18] International Organization For Standardization (ISO), "ISO - ISO 14040:2006 - Environmental management - Life cycle assessment Principles and framework," 2006. https://www.iso.org/standard/37456.html (accessed Sep. 04, 2020).

[19] International Organization For Standardization (ISO), "ISO - ISO 14041:1998 - Environmental management - Life cycle assessment — Goal and scope definition and inventory analysis," 1998. https://www.iso.org/standard/23152.html (accessed Sep. 04, 2020).

[20] International Organization For Standardization (ISO), "ISO - ISO 14042:2000 - Environmental management - Life cycle assessment — Life cycle impact assessment," 2000. https://www.iso.org/standard/23153.html (accessed Sep. 04, 2020).

[21] International Organization For Standardization (ISO), "ISO - ISO 14043:2000 - Environmental management — Life cycle assessment — Life cycle interpretation," 2000. https://www.iso.org/standard/23154.html (accessed Sep. 04, 2020).

[22] M. M. Khasreen, P. F. G. Banfill, and G. F. Menzies, "Life-Cycle Assessment and the Environmental Impact of Buildings: A Review," Sustainability, vol. 1, no. 3, pp. 674701, Sep. 2009, doi: 10.3390/su1030674.

[23] A. A. M. Ali, "Application of comparative life cycle assessment to a proposed building for reduced environmental impacts: Assiut University Hospital Clinic as a case study," $J$. Archit. Arts Humanit. Sci., vol. 7, no. 31, 2021, doi: 10.21608/mjaf.2020.41904.1847.

[24] A. A. M. Ali, "An Integrated Analysis With Life Cycle Assessment, Building Information Modeling, And Environmental Performance For Window Materials: Assiut University 
Hospital Clinic As A Case Study," JES. J. Eng. Sci., vol. 48, no. 6, pp. 1024-1050, Oct. 2020, doi: 10.21608/jesaun.2020.42055.1009.

[25] M. Najjar, K. Figueiredo, A. W. A. Hammad, and A. Haddad, "Integrated optimization with building information modeling and life cycle assessment for generating energy efficient buildings," Appl. Energy, vol. 250, no. January, pp. 1366-1382, 2019, doi: 10.1016/j.apenergy.2019.05.101.

[26] S. Seyis, "Mixed method review for integrating building information modeling and life-cycle assessments," Build. Environ., vol. 173, no. January, p. 106703, 2020, doi: 10.1016/j.buildenv.2020.106703.

[27] S. Su, Q. Wang, L. Han, J. Hong, and Z. Liu, "BIM-DLCA: An integrated dynamic environmental impact assessment model for buildings," Build. Environ., vol. 183, no. May, p. 107218, 2020, doi: 10.1016/j.buildenv.2020.107218.

[28] C. Ingrao, A. Messineo, R. Beltramo, T. Yigitcanlar, and G. Ioppolo, "How can life cycle thinking support sustainability of buildings? Investigating life cycle assessment applications for energy efficiency and environmental performance," J. Clean. Prod., vol. 201, pp. 556-569, 2018, doi: 10.1016/j.jclepro.2018.08.080.

[29] M. U. Hossain and S. Thomas Ng, "Influence of waste materials on buildings' life cycle environmental impacts: Adopting resource recovery principle," Resour. Conserv. Recycl., vol. 142, no. October 2018, pp. 10-23, 2019, doi: 10.1016/j.resconrec.2018.11.010.

[30] A. A. M. M. Ali, A. M. Negm, M. F. Bady, M. G. E. Ibrahim, and M. Suzuki, "Environmental impact assessment of the Egyptian cement industry based on a life-cycle assessment approach: a comparative study between Egyptian and Swiss plants," Clean Technol. Environ. Policy, vol. 18, no. 4, 2016, doi: 10.1007/s10098-016-1096-0.

[31] S. G. Al-Ghamdi and M. M. Bilec, "Green Building Rating Systems and Whole-Building Life Cycle Assessment: Comparative Study of the Existing Assessment Tools," J. Archit. Eng., vol. 23, no. 1, pp. 1-9, 2017, doi: 10.1061/(ASCE)AE.1943-5568.0000222.

[32] A. A. M. Ali, A. M. Negm, M. F. Bady, M. G. E. Ibrahim, and M. Suzuki, "Environmental impact assessment of the Egyptian cement industry based on a life-cycle assessment approach: a comparative study between Egyptian and Swiss plants," Clean Technol. Environ. Policy, vol. 18, no. 4, pp. 1053-1068, 2016, doi: 10.1007/s10098-016-1096-0.

[33] D. Eliche-Quesada, M. A. Felipe-Sesé, J. A. López-Pérez, and A. Infantes-Molina, "Characterization and evaluation of rice husk ash and wood ash in sustainable clay matrix bricks," Ceram. Int., vol. 43, no. 1, pp. 463475, 2017, doi: 10.1016/j.ceramint.2016.09.181.

[34] Brick Industry Association, "Sustainability and Brick, Technical Notes on Brick Construction," Brick Ind. Assoc., no. November, pp. 1-10, 2009.

[35] G. Garas, E. Bakhoum, and M. Allam, "Rice straw-cementitious bricks: Analytical study on mechanical properties and sustainability measures," ARPN J. Eng. Appl. Sci., vol. 10, no. 18, pp. 7959-7968, 2015.

[36] N. Said, S. A. El-Shatoury, L. F. Díaz, and M. Zamorano, "Quantitative appraisal of biomass resources and their energy potential in Egypt," Renew. Sustain. Energy Rev., vol. 24, pp. 8491, 2013, doi: 10.1016/j.rser.2013.03.014.

[37] N. N Atta and A. A El Baz, "Anaerobic CoDigestion of Wastewater Activated Sludge and Rice Straw in Batch and Semi Continuous Modes," J. Fundam. Renew. Energy Appl., vol. 06, no. 02, 2016, doi: 10.4172/20904541.1000204 
Vol. 41, No.2. July 2022

تقييم الآثار البيئية لطوب قش الأرز كمواد بناء بديلة مستدامة في عيادة مستشفى جامعة أسيوط

أحمد عبد المنطلب محمد علي

أستاذ مساعد بقسم العمارة، كلية العمارة والتخطيط، جامعة القصيم، القصيم 52571، المملكة العربية السعودية البريد الالكتروني: ahm.ali@qu.edu.sa، رقمة الهاتف 966532490093،

مدرس بقسم الهندسة المعمارية، كلية الهندسة، جامعة أسيوط، أسيوط

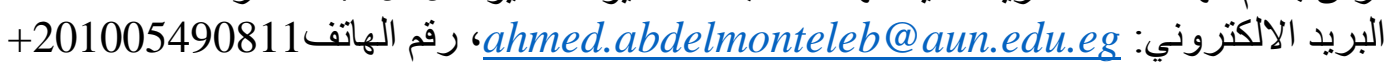

يحدث حرق محصول قش الأرز في جميع المحافظات المصرية بشكل موسمي، وهي كارثة بيئية تسمى "السحابة السوداء". باستخدام منهجيات تقييم دورة الحياة (LCA) ونمذجة معلومات البناء (BIM)، نم إجر اء هذه الدر اسة. الهدف من هذا البحث هو هوري مقارنة أنواع الطوب الأربعة: (1) الطوب الطيني المحروق، (2) الطوب الأسمنتي، (3) الطوب الرملي، (4) طوب فش الأرز من وجهة نظر التأثيرات البيئية. ينم استخدام BIM لتجميع مكونات تثييد المبنى لبناء سيناريوهات LCA الأربعة باستخدام برنامج PRe SimaPro نقطة المنتصف (Midpoint method) ونقطة النهاية (Endpoint method) باستخدام النقطة (Pt) كوحدة قياس. (1) وفقًا لنتائج تحليل نقطة المنتصف، سجل الطوب الطيني أسوأ تأثير بيئي بمقدار 30.10 نقطة. في المقابل، فإن طوب قش الأرز تحقق أقل تأثير بـ 1.31 وحدة. بالانتقال إلى الطوب الأسمنتي و الطوب الرملي فقد نم تسجيل المر اتب الوسطى بـ 14.20 نقطة و10.80 نقطة على الترتيب. (2) وفقًا لنتائج تحليل نقطة النهاية، تم تخصيص أعلى قيمة لتأثير صحة الإنسان لنوع الطوب الطيني المحروق بمقدار 11.4 نقطة، وطوب قش الأرز بنسبة 0.633 نقطة. كما تم الإشارة إلى أعلى تأثير ات استنفاد للموارد على الطين المحروق و الطوب الأسمنتي 7.29 نقطة و6.53 نقطة على الترتيب. أخيرًا، خلصت الورقة إلى أهمية تطبيق LCA لإنتاج مواد بناء مستدامة وتخفيف الآثار البيئية السلبية لصناعة الطوب. كما قدمت الورقة نهج للتخلص من النقص في قاعدة بيانات دورة الحياة المصرية. علاوة على ذلك، يمكن أن تساعد الهيئات التشريعية المعنية ومتخذي القرار.

الكلمات المفتاحية تقييم الأثر البيئي، تقييم دورة الحياة، نمذجة معلومات المباني، طوب قش الأرز، مدينة أسيوط 